\title{
Pengaruh Motivasi Kerja Guru, Disiplin Kerja Guru, Dan Fasilitas Belajar Siswa Terhadap Prestasi Belajar Siswa
}

\author{
Muazza, Marzul Hidayat, Riscky Fitri Wahyuni, Mohamad Muspawi* \\ Universitas Jambi, Indonesia \\ Corresponding Authors: mohamad.muspawi@unja.ac.id
}

\begin{abstract}
ABSTRAK
Penelitian ini bertujuan untuk menganalisis bagaimana pengaruh motivasi kerja, disiplin kerja guru, dan fasilitas belajar terhadap prestasi belajar siswa kelas $X$ di SMK DB 4 Kota Jambi. Penelitian ini merupakan penelitian kuantitatif dengan metode survei untuk menguji hipotesis atau menjawab pertanyaan yang berkaitan dengan current status dari subjek yang diteliti. Penelitian ini terdiri dari 98 sampel dan angket yang kembali sebanyak 84 orang. Hasil penelitian menunjukkan bahwa terdapat pengaruh positif dan signifikan motivasi kerja guru terhadap terhadap hasil belajar / prestasi belajar siswa dengan koefisian determinasi sebesar 0,438. Terdapat pengaruh positif dan signifikan antara disiplin kerja terhadap hasil belajar/prestasi dengan koefisien determinasi sebanyak 0,287. Terdapat pengaruh positif dan signifikan antara disiplin kerja terhadap hasil belajar/ prestasi dengan koefisien determinasi sebanyak 0,411. Kemudian, terdapat pengaruh positif dan signifikan antara motivasi kerja guru, disiplin kerja guru, dan fasilitas belajar siswa terhadap hasil belajar/prestasi dengan koefisien determinasi sebesar 0,506. Berdasarkan hasil penelitian ini, guru - guru SMK DB 4 Kota Jambi disarankan agar dapat mempertahankan dan meningkatkan motivasi kerja yang telah dicapai baik dalam kualitas maupun proses pembelajaran serta tidak merasa cepat puas dengan apa yang telah dicapai agar terciptanya suasana belajar yang baik dan kondisuf.
\end{abstract}

Kata Kunci: Motivasi, disiplin, fasilitas dan prestasi

\section{PENDAHULUAN}

Prestasi belajar siswa adalah hal yang menjadi patokan untuk melihat hasil dari proses belajar mengajar. Prestasi belajar bisa menjadi kebanggaan bagi orang tua bila anaknya mendapat prestasi belajar yang baik dan sebaliknya menjadi kemarahan orang tua bila anaknya mendapat prestasi belajar yang kurang baik. Hasbiah (2008) mengatakan prestasi belajar adalah apa yang telah dicapai oleh siswa setelah melakukan kegiatan belajar mengajar. Sudjana (2011) mengatakan prestasi/hasil belajar merupakan kemampuan-kemampuan yang dimiliki siswa setelah ia menerima pengalaman belajarnya. Prestasi belajar juga menjadi motivasi siswa untuk meningkatkan belajarnya atau untuk berusaha mempertahankan prestasi 
yang telah diraih. Prestasi belajar yang baik tidak hanya di dapat dari anak yang rajin belajar, anak yang cerdas dan anak yang memiliki IQ tinggi. Tapi banyak faktor yang mempengaruhi seorang siswa mendapat prestasi belajar yang baik, diantaranya adalah faktor kerajinan, faktor guru, lingkungan sekolah dan rumah. Semua faktor itu memiliki kontribusi terhadap pendapatan prestasi belajar siswa, biasanya kesemua faktor itu saling berhubungan.

Motivasi kerja guru adalah suatu dorongan untuk guru melakukan tugasnya dengan sebaik-baiknya. Motivasi kerja guru ini bermanfaat bagi siswa agar proses belajar mengajar menjadi efektif. Apabila guru mempunyai motivasi kerja yang tinggi maka semangat itu akan menular ke siswa dan siswa menjadi semangat dalam belajar. Begitu juga sebaliknya jika guru bermalas-malasan seperti tidak ada motivasi dalam dirinya untuk mengajar maka siswa juga merasa lemas dan malas serta tidak bersemangat dalam mengikuti proses belajar mengajar. Motivasi merupakan sikap dan nilai yang dimiliki guru yang dapat mempengaruhi cara mengajarnya dan juga dapat mempengaruhi siswa untuk dapat mencapai tujuan pembelajaran. (Erina, 2014). Muspawi (2020) mengatakan bahwa kesuksesan seorang guru dalam mengajar dapat dipengaruhi oleh tingginya motivasi yang dimiliki oleh guru tersebut. Dengan motivasi yang baik maka guru biasanya menunjukkan kinerja yang maksimal, semangat dalam mengajar, tekun dalam menghadapi berbagai halangan dan rintangan atas pekerjaannya sebagai seorang guru.

Seorang guru yang profesional sebaiknya tidak terpengaruh keadaaan sekitar untuk dapat termotivasi dalam pekerjaan. Apapun masalah yang sedang dihadapi guru tetap harus semangat dan fokus mengajar agar ilmu yang disampaikan dapat diterima dengan baik oleh siswa. Motivasi guru untuk mengajar harus terus tinggi tidak peduli masalah apa yang sedang dihadapinya. Hal itu yang membuat guru menjadi seorang guru yang propesional.

Disiplin kerja yang dimiliki guru merupakan hal yang penting. Guru yang datang ke sekolah tepat waktu dan pulang sesuai dengan jam belajar guru. Guru yang masuk ke kelas mengajar sesuai dengan waktunya, masuk dan keluar tepat waktu. Guru yang mengajar sesuai dengan tujuan pembelajaran. Hal-hal tersebut merupakan contoh yang dapat membangkitkan semangat siswa dalam belajar. Menurut Sholeh (2006) dalam menegakkan disiplin merupakan hal yang sangat penting, sebab dengan kedisiplinan dapat diketahui seberapa besar peraturanperaturan dapat ditaati oleh guru. dengan kedisiplinan di dalam mengajar guru proses pembelajaran akan terlaksana secara efektif dan efisien. Dengan adanya kesadaran diri untuk menerapkan kedisiplinan di dalam mengajar, diharapkan semua kegiatan sehari-hari juga dapat menerapkan kedisiplinan sesuai dengan tujuan yang telah ditetapkan.

Kurang disiplinnya guru-guru dalam melaksanakan tugas, seperti datang ke sekolah terlambat, bersikap masa bodoh terhadap siswa berakibat kualitas peserta didik menjadi rendah. Rendahnya tingkat kedisiplinan guru di dunia pendidikan 
dapat menghambat kegiatan belajar- mengajar di sekolah. Dari organisasi atau instansi sendiri juga berperan dalam mengelola guru agar mematuhi segala peraturan, norma yang telah ditetapkan oleh sekolah sehingga para guru bekerja dengan disiplin dan efektif.

Fasilitas belajar siswa di sekolah menjadi hal penting karena merupakan penunjang kelancaran kegiatan belajar mengajar. Siswoyo (2011) menyatakan bahwa fasilitas atau alat pendidikan adalah segala sesuatu yang digunakan untuk membantu tercapainya tujuan pendidikan. Fasilitas belajar yang diberikan sekolah seharusnya dapat dimanfaatkan dengan baik dan dirawat sebaik mungkin agar dapat membantu siswa menerima ilmu dengan maksimal. Akan tetapi saat ini di Indonesia penyediaan fasilitas belajar belum merata, hanya di sekolah-sekolah tertentu saja yang memiliki fasilitas lengkap, sedangkan di daerah terpencil malah terkadang fasilitasnya sangat menyedihkan. Mereka sangat kekurangan fasilitas dalam belajar, jangankan penyediaan komputer dan internet sebagaimana yang dibutuhkan pada saat ini, meja dan kursi saja mereka cenderung kekurangan bahkan ada sekolah yang masih berlantaikan tanah. Berdasarkan uraian latar belakang tersebut penulis tertarik untuk melakukan penelitian tentang Pengaruh Motivasi kerja guru, Disiplin Kerja guru, dan Fasilitas belajar siswa terhadap Prestasi belajar siswa Kelas X Di SMK DB 4 Kota Jambi.

\section{METODE PENELITIAN}

Penelitian ini menggunakan metode kuantitatif dengan pendekatan survey. Metode ini dipakai untuk mengembangkan variabel-variabel yang diteliti dengan menggunakan model- model matematis, teori-teori dan menguji hipotesis yang akan menghasilkan data statistik. Instrumen yang digunakan berupa angket. Penelitian ini dilaksanakan di SMK DB 4 Kota Jambi, dikarenakan di sekolah tersebut terdapat banyak siswa yang bermasalah dalam mencapai prestasi belajar. Penelitian dilaksanakan pada bulan Januari sampai Februari 2020. Populasi dalam penelitian ini adalah seluruh siswa kelas X SMK DB 4 Kota Jambi yang berjumlah 98 orang. Sedangkan sampel dalam penelitian ini berjumlah 98 orang.

\section{HASIL PENELITIAN DAN PEMBAHASAN}

\section{Hasil Pengujian Hipotesis 1 Uji Statistik T}

Uji statistik $\mathrm{t}$ digunakan untuk mengetahui apakah variabel independen (X) berpengaruh secara signifikan terhadap variabel dependen $(Y)$. Pengujian parameter individual dimaksudkan untuk melihat apakah variabel secara individu mempunyai pengaruh terhadap variabel tak bebas dengan asumsi variabel bebas lainnya konstan (Ghozali, 2011).

Untuk mengetahui pengaruh itu signifikan atau tidak adalah melalui 
perhitungan yang dapat digunakan untuk menerima atau menolak hipotesis yang dirumuskan, yaitu dengan melihat dan membandingkan antara nilai thitung dengan tabel pada tingkat keyakinan 95\% $(\alpha=0,05)$, dengan kriteria keputusan:

- Jika thitung $<\mathrm{t}_{\text {tabel }}$ : $\mathrm{H}_{0}$ diterima atau $\mathrm{H}_{\alpha}$ ditolak

- Jika thitung $>t_{\text {tabel }}: \mathrm{H}_{\alpha}$ diterima atau $\mathrm{H}_{0}$ ditolak

Alternatif lain yang dapat digunakan untuk menerima atau menolak hipotesis yang dirumuskan, yaitu dengan melihat signifikansi lebih kecil dari 0,05 maka $\mathrm{H}_{0}$ ditolak atau $\mathrm{H}_{\alpha}$ diterima artinya secara parsial variabel bebas tersebut bepengaruh secara signifikan terhadap variabel terikat (Ghozali, 2011).

Berikut merupakan hasil pengujian statisitik t yang disajikan pada tabel di bawah ini:

Tabel 1. Coefesien

\begin{tabular}{|c|c|c|c|c|c|}
\hline \multirow[t]{2}{*}{ Model } & \multicolumn{2}{|c|}{$\begin{array}{l}\text { Unstandardized } \\
\text { Coefficients }\end{array}$} & $\begin{array}{l}\text { Standardized } \\
\text { Coefficients }\end{array}$ & $\mathrm{T}$ & Sig. \\
\hline & B & Std. Error & Beta & & \\
\hline (Constant) & 1,096 & 8,910 & &,- 123 & 902 \\
\hline Motivasi kerja & ,634 & ,079 & 662 & 7,998 & ,000 \\
\hline
\end{tabular}

Dependent Variable: Hasil belajar

Berdasarkan tabel 1 dapat dijelaskan bahwa pengujian hipotesis 1, dilakukan dengan membandingkan thitung dengan ttabel. Dari tabel dapat dilihat nilai thitung variabel $\left(\mathrm{X}_{1}\right)$ adalah sebesar 7,998. Sedangkan tabel dapat dilihat dari tabel statistik taraf signifikan 0,05 (uji dua sisi) dengan derajat kebebasan (df) n-k atau 82-4=78, nilai tabel yang diperoleh sebesar 1,990 sehingga thitung $>t_{\text {tabel }}(7,998>1,996)$ maka $\mathrm{H}_{0}$ ditolak. Nilai signifikan variabel $\left(X_{1}\right)$ adalah sebesar $0,000(<0,05)$ dengan nilai $\beta$ sebesar 0,000 . Dengan demikian $H_{0}$ ditolak dan menerima $H_{\alpha}$. Hal ini menunjukkan bahwa Motivasi kerja berpengaruh positif dan signifikan terhadap Hasil belajar Siswa.

Hipotesis yang di uji dalam penelitian ini adalah hipotesis alternative (Ha) yang berbunyi Apakah terdapat pengaruh antara Motivasi Kerja Guru terhadap Hasil belajar/Prestasi Belajar siswa. Dari hasil perhitungan dengan SPSS 21 besarnya kontribusi variabel Motivasi Kerja terhadap $\left(X_{1}\right)$ terhadap Hasil belajar/prestasi Belajar siswa $(Y)$ dalam artian dianalisis kemampuan variabel prediktor $\left(\mathrm{X}_{1}\right)$ dalam memprediksi variabel kriteriumnya. Dari hasil penelitian ini diperoleh koefesien determinasi $\left(\mathrm{R}^{2}\right)$ sebagaimana dijelaskan pada tebel berikut: 
Tabel 2. Motivasi Guru ( $\left.\mathrm{X}_{1}\right)$ Terhadap Hasil Belajar siswa (Y)

\begin{tabular}{|c|c|c|c|c|}
\hline ModeL & $\mathrm{R}$ & R Square & $\begin{array}{l}\text { Adjusted } \mathrm{R} \\
\text { Square }\end{array}$ & $\begin{array}{l}\text { Std. Error of } \\
\text { the Estimate }\end{array}$ \\
\hline 1 &, $662^{a}$ & ,438 & 431 & 3,393 \\
\hline
\end{tabular}

Koefesien Determinasi $\left(\mathrm{R}^{2}\right)$ merupakan cara untuk menilai seberapa besar konstruk endogen dapat dijelaskan oleh konstruk eksogen. Nilai koefisien determinasi $\left(R^{2}\right)$ diharapkan antara 0 dan 1 . Jika nilai $R^{2} 0,75$, 0,50, dan 0,25 menunjukkan bahwa model kuat, moderat, dan lemah (Sarstedt dkk., 2017). Chin dalam Ghozali dan Latan (2015) memberikan kriteria nilai $\mathrm{R}^{2}$ sebesar 0,$67 ; 0,33$; dan 0,19 sebagian kuat, moderat, dan lemah. Adapun hasil pengukuran penelitian ini dengan menggunakan koefesien determinasi $\left(\mathrm{R}^{2}\right)$ dapat dilihat pada tabel 2 tersebut.

$\mathrm{R}$ menunjukkan regresi Motivasi Kerja Guru sekolah Terhadap Hasil belajar/ Prestasi belajar siswa yaitu 0,438 masuk dalam kategori Moderat. Adapun R Square pada tabel di atas menunjukkan nilai koefesien determinasi Motivasi Kerja guru Terhadap Prestasi/ Hasil Belajar siswa sebesar 0,438 atau sebesar 30,04\%. Dengan demikian, berarti bahwa Hasil belajar siswa diprediksi sebesar 30,04\% dapat dijelaskan oleh Motivasi Kerja guru sisanya sebesar 70,0\% dijelaskan oleh variablevariabel yang belum dimasukkan ke dalam model.

\section{Hasil Pengujian Hipotesis 2 Uji Statistik T}

Tabel 3. Coefesien

\begin{tabular}{|c|c|c|c|c|c|}
\hline \multirow[t]{2}{*}{ Model } & \multicolumn{2}{|c|}{$\begin{array}{l}\text { Unstandardized } \\
\text { Coefficients }\end{array}$} & \multirow{2}{*}{$\begin{array}{l}\text { Standardize } \\
\mathrm{d} \\
\text { Coefficients } \\
\text { Beta }\end{array}$} & \multirow[t]{2}{*}{ t } & \multirow[t]{2}{*}{ Sig. } \\
\hline & B & Std. Error & & & \\
\hline (Constant) & 37,733 & 5,649 & & 6,680 & 000 \\
\hline Disiplin Kerja & ,501 & 087 & ,536 & 5,747 & 000 \\
\hline
\end{tabular}

Dependent Variable: Hasil belajar

Berdasarkan tabel 3 dapat dijelaskan bahwa pengujian hipotesis 2, dilakukan dengan membandingkan thitung dengan ttabel. Dari tabel dapat dilihat nilai thitung variabel $\left(\mathrm{X}_{2}\right)$ adalah sebesar 5,747. Sedangkan tabel dapat dilihat dari tabel statistik taraf signifikan 0,05 (uji dua sisi) dengan derajat kebebasan (df) n-k atau 82-4=78, nilai tabel yang diperoleh sebesar 1,990 sehingga thitung $>$ tabel $(5,747>1,996)$ maka $\mathrm{H}_{0}$ ditolak. Nilai signifikan variabel $\left(X_{1}\right)$ adalah sebesar $0,000(<0,05)$ dengan nilai $\beta$ sebesar 0,000 . Dengan demikian $\mathrm{H}_{\circ}$ ditolak dan menerima $\mathrm{H}_{\alpha}$. Hal ini menunjukkan bahwa Disiplin 
kerja Guru berpengaruh positif dan signifikan terhadap Hasil belajar Siswa.

Hipotesis yang di uji dalam penelitian ini adalah hipotesis alternative (Ha) yang berbunyi Apakah terdapat pengaruh antara Disiplin Kerja Guru terhadap Hasil belajar/Prestasi Belajar siswa. Dari hasil perhitungan dengan SPSS 21 besarnya kontribusi variabel Disiplin kerja terhadap $\left(X_{2}\right)$ terhadap Hasil belajar/prestasi Belajar siswa ( $Y$ ) dalam artian dianalisis kemampuan variabel prediktor $\left(X_{1}\right)$ dalam memprediksi variabel kriteriumnya. Dari hasil penelitian ini diperoleh koefesien determinasi $\left(\mathrm{R}^{2}\right)$ sebagaimana dijelaskan pada tebel berikut:

Tabel 4. Disiplin kerja $\left(\mathrm{X}_{2}\right)$ Terhadap Hasil Belajar siswa $(\mathrm{Y})$

\begin{tabular}{|l|l|l|l|l|}
\hline Model & $R$ & R Square & $\begin{array}{l}\text { Adjusted } \mathrm{R} \\
\text { Square }\end{array}$ & $\begin{array}{l}\text { Std. Error of } \\
\text { the Estimate }\end{array}$ \\
\hline 1 & $536^{\mathrm{a}}$ & 287 & 278 & 3,822 \\
\hline
\end{tabular}

Predictors: (Constant), Disiplin Kerja

Koefesien Determinasi $\left(\mathrm{R}^{2}\right)$ merupakan cara untuk menilai seberapa besar konstruk endogen dapat dijelaskan oleh konstruk eksogen. Nilai koefisien determinasi $\left(\mathrm{R}^{2}\right)$ diharapkan antara 0 dan 1 . Jika nilai $\mathrm{R}^{2} 0,75,0,50$, dan 0,25 menunjukkan bahwa model kuat, moderat, dan lemah (Sarstedt dkk., 2017). Chin dalam Ghozali dan Latan (2015) memberikan kriteria nilai $\mathrm{R}^{2}$ sebesar 0,67; 0,33; dan 0,19 sebagian kuat, moderat, dan lemah. Adapun hasil pengukuran penelitian ini dengan menggunakan koefesien determinasi $\left(\mathrm{R}^{2}\right)$ dapat dilihat pada tabel 4 tersebut.

$\mathrm{R}$ menunjukkan regresi Disiplin Kerja Guru sekolah Terhadap Hasil belajar/ Prestasi belajar siswa yaitu 0,287 masuk dalam kategori Lemah. Adapun R Square pada tabel di atas menunjukkan nilai koefesien determinasi disiplin Kerja guru Terhadap Prestasi/ Hasil Belajar siswa sebesar 0,287 atau sebesar 28,7\%. Dengan demikian, berarti bahwa Hasil belajar siswa diprediksi sebesar 28,7\% dapat dijelaskan oleh Disiplin Kerja guru sisanya sebesar 71,3\% dijelaskan oleh variablevariabel yang belum dimasukkan ke dalam model.

Tabel 5. Koefesien Determinasi Disiplin Kerjra $\left(\mathrm{X}_{2}\right)$ Dengan hasil beajar Siswa $(Y)$

\begin{tabular}{|c|c|c|c|c|c|}
\hline \multicolumn{6}{|l|}{ Coefficients $^{a}$} \\
\hline \multirow[t]{2}{*}{ Model } & \multicolumn{2}{|c|}{$\begin{array}{l}\text { Unstandardized } \\
\text { Coefficients }\end{array}$} & \multirow{2}{*}{\begin{tabular}{|l} 
Standardize \\
d \\
Coefficients \\
Beta
\end{tabular}} & \multirow[t]{2}{*}{$T$} & \multirow[t]{2}{*}{ Sig. } \\
\hline & B & Std. Error & & & \\
\hline (Constant) & 37,604 & 4,318 & & 8,709 &, 000 \\
\hline $\begin{array}{l}\text { Fasilitas } \\
\text { Belajar }\end{array}$ & 652 & 086 & 641 & 7,557 &, 000 \\
\hline
\end{tabular}


Berdasarkan tabel 5 dapat dijelaskan bahwa pengujian hipotesis 3, dilakukan dengan membandingkan thitung dengan ttabel. Dari tabel dapat dilihat nilai thitung variabel $\left(X_{3}\right)$ adalah sebesar 7,557. Sedangkan tabel dapat dilihat dari tabel statistik taraf signifikan 0,05 (uji dua sisi) dengan derajat kebebasan (df) n-k atau 82-4=78, nilai tabel yang diperoleh sebesar 1,990 sehingga thitung $>t_{\text {tabel }}(7,557>1,996)$ maka $H_{0}$ ditolak. Nilai signifikan variabel $\left(X_{1}\right)$ adalah sebesar $0,000(<0,05)$ dengan nilai $\beta$ sebesar 0,000 . Dengan demikian $\mathrm{H}_{\mathrm{o}}$ ditolak dan menerima $\mathrm{H}_{\alpha}$. Hal ini menunjukkan bahwa Fasilitas Belajar berpengaruh positif dan signifikan terhadap Hasil belajar Siswa.

Hipotesis yang di uji dalam penelitian ini adalah hipotesis alternative (Ha) yang berbunyi Apakah terdapat pengaruh antara Fasilitas belajar terhadap Hasil belajar/Prestasi Belajar siswa. Dari hasil perhitungan dengan SPSS 21 besarnya kontribusi variabel Fasilitas belajar terhadap $\left(X_{3}\right)$ terhadap Hasil belajar/prestasi Belajar siswa $(\mathrm{Y})$ dalam artian dianalisis kemampuan variabel prediktor $\left(\mathrm{X}_{1}\right)$ dalam memprediksi variabel kriteriumnya. Dari hasil penelitian ini diperoleh koefesien determinasi $\left(\mathrm{R}^{2}\right)$ sebagaimana dijelaskan pada tebel berikut:

Tabel 6. Fasilitas Belajar $\left(\mathrm{X}_{3}\right)$ Terhadap Hasil Belajar siswa $(\mathrm{Y})$

\begin{tabular}{|l|l|l|l|l|}
\hline Model & R & R Square & $\begin{array}{l}\text { Adjusted R } \\
\text { Square }\end{array}$ & $\begin{array}{l}\text { Std. Error of } \\
\text { the Estimate }\end{array}$ \\
\hline 1 & $641^{\mathrm{a}}$ & 411 & 403 & 3,475 \\
\hline
\end{tabular}

Predictors: (Constant), Fasilitas Belajar

Koefesien Determinasi $\left(\mathrm{R}^{2}\right)$ merupakan cara untuk menilai seberapa besar konstruk endogen dapat dijelaskan oleh konstruk eksogen. Nilai koefisien determinasi $\left(\mathrm{R}^{2}\right)$ diharapkan antara 0 dan 1 . Jika nilai $\mathrm{R}^{2} 0,75,0,50$, dan 0,25 menunjukkan bahwa model kuat, moderat, dan lemah (Sarstedt dkk., 2017). Chin dalam Ghozali dan Latan (2015) memberikan kriteria nilai $\mathrm{R}^{2}$ sebesar 0,67; 0,33; dan 0,19 sebagian kuat, moderat, dan lemah. Adapun hasil pengukuran penelitian ini dengan menggunakan koefesien determinasi $\left(\mathrm{R}^{2}\right)$ dapat dilihat pada tabel 6 diatas.

$\mathrm{R}$ menunjukkan regresi Fasilitas belajar siswa Terhadap Hasil belajar/ Prestasi belajar siswa yaitu 0,411 masuk dalam kategori Moderat. Adapun R Square pada tabel di atas menunjukkan nilai koefesien determinasi disiplin Kerja guru Terhadap Prestasi/ Hasil Belajar siswa sebesar 0,411 atau sebesar 41,1\%. Dengan demikian, berarti bahwa Hasil belajar siswa diprediksi sebesar 41,1\% dapat dijelaskan oleh Fasilitas belajar siswa sisanya sebesar 58,9\% dijelaskan oleh variable-variabel yang belum dimasukkan ke dalam model.

\section{Hasil pengujian hipotesis 4 (Uji F)}

Hipotesis yang keempat yang dikemukakan dalam penenlitian ini adalah terdapat pengaruh positif dan signifikan secara simultan antara Motivasi Kerja, Disiplin, dan fasilitas Hasil belajar Siswa Kelas X SMK DB 4 Kota jambi Analisis yang digunakan 
adalah Apabila Fhitung lebih besar dari pada $F_{\text {tabel }}$ maka $\mathrm{H}_{\mathrm{o}}$ ditolak. Pengujian ini dilakukan dengan membandingkan $F_{\text {hitung dengan }} \mathrm{Ftabel}$

Tabel 7. Koefesien Determinasi Regresi Variabel Motivasi kerja Guru(X1), Disiplin Kerja Guru X2) dan Fasilitas Belajar siswa (X3) hasil belajar siswa (Y)

ANOVA $^{\mathrm{a}}$

\begin{tabular}{|l|l|l|l|l|l|l|}
\hline \multicolumn{2}{|l|}{ Model } & $\begin{array}{l}\text { Sum of } \\
\text { Squares }\end{array}$ & df & $\begin{array}{l}\text { Mean } \\
\text { Square }\end{array}$ & F & Sig. \\
\cline { 1 - 4 } & Regression & 850,088 & 3 & 283,363 & 27,314 & $000^{\mathrm{b}}$ \\
\cline { 1 - 4 } 1 & Residual & 829,948 & 80 & 10,374 & & \\
\hline
\end{tabular}

a. Dependent Variable: Hasil belajar

b. Predictors: (Constant), Fasilitas Belajar, Disiplin Kerja, Motivasi kerja

Dari tabel diatas diketahui nilai Fhitung sebesar 27,214. Nilai ftabel dapat dilihat pada tabel statistik dengan taraf signifikansi 0.05 dengan derajat kebebasan (df1) k-1 atau 4-1=3, (df2) n-k atau 82-4=78, nilai ftabel yang diperoleh sebesar 2.49 sehingga fhitung $>\mathrm{f}_{\text {tabel }}$ yaitu sebesar $\left(27,314>2.49\right.$ maka $\mathrm{H}_{0}$ ditolak dan menerima $\mathrm{H}_{\alpha}$, dengan tingkat signifikan sebesar $0.000(<0.05)$. Maka pengujian diatas menunjukkan bahwa terdapat pengaruh antara Motivasi Guru, Disiplin Kerja, dan Fasilitas belajar secara simultan terhadap hasil belalajar siswa di SMK DB 4 Kota Jambi.

Tabel 8. Motivasi Kerja, Disiplin Kerja dan Fasilitas Belajar Terhadap Hasil Belajar Siswa

Model Summary

\begin{tabular}{|c|r|l|l|l|}
\hline $\begin{array}{c}\text { Mode } \\
1\end{array}$ & $R$ & $R$ Square & $\begin{array}{c}\text { Adjusted R } \\
\text { Square }\end{array}$ & $\begin{array}{l}\text { Std. Error of } \\
\text { the Estimate }\end{array}$ \\
\hline 1 &, $711^{\mathrm{a}}$ & 506 & 487 & 3,221 \\
\hline
\end{tabular}

Predictors: (Constant), Fasilitas Belajar, Disiplin Kerja, Motivasi kerja

Koefesien Determinasi $\left(\mathrm{R}^{2}\right)$ merupakan cara untuk menilai seberapa besar konstruk endogen dapat dijelaskan oleh konstruk eksogen. Nilai koefisien determinasi $\left(\mathrm{R}^{2}\right)$ diharapkan antara 0 dan 1 . Jika nilai $\mathrm{R}^{2} 0,75,0,50$, dan 0,25 menunjukkan bahwa model kuat, moderat, dan lemah (Sarstedt dkk., 2017). Chin dalam Ghozali dan Latan (2015) memberikan kriteria nilai $\mathrm{R}^{2}$ sebesar 0,67; 0,33; dan 0,19 sebagian kuat, moderat, dan lemah. Adapun hasil pengukuran penelitian ini dengan menggunakan koefesien determinasi $\left(\mathrm{R}^{2}\right)$ dapat dilihat pada tabel 8 diatas.

Berdasarkan analisis tabel di atas menunjukkan angka Adjust $R$ Square adalah 0, 506 masuk dalam kategori moderat artinya 50,6\% variabel terikat Hasil belajar/prestasi belajar siswa yang dijelaskan oleh variabel bebas yang terdiri dari 
Motivasi kerja guru, Disiplin kerja guru, Fasilitas blajar siswa dan dan sisanya sebesar 49,70 \% dijelaskan oleh variabel lain diluar variabel yang digunakan. Jadi sebagian besar variabel terikat dijelaskan oleh variabel diluar variabel-variabel bebas yang tidak digunakan dalam model ini.

Tabel 9. Hasil Pengujian Hipotesis

\begin{tabular}{|c|c|c|c|c|c|c|}
\hline \multirow[t]{2}{*}{ No. } & \multirow[t]{2}{*}{ Hipotesis } & \multicolumn{4}{|c|}{ Perbandingan } & \multirow[t]{2}{*}{ Kesimpulan } \\
\hline & & $\begin{array}{l}\text { thitun } \\
\mathrm{g}\end{array}$ & ttabel & fhitung & $\begin{array}{l}\text { Ftabe } \\
1\end{array}$ & \\
\hline 1 & $\begin{array}{l}\text { 'erdapat Pengaruh antara } \\
\text { Motivasi terhadap Hasil } \\
\text { belajar }\end{array}$ & 7,998 & 1,990 & & & $\begin{array}{l}\text { thitung }>\text { tabel yang } \\
\text { menyatakan bahwa } \\
H_{\text {a diterima yang }} \\
\text { berarti } H_{1} \text { diterima }\end{array}$ \\
\hline 2 & $\begin{array}{l}\text { Terdapat Pengaruh } \\
\text { Disiplin Kerja terhadap } \\
\text { Hasil belajar siswa }\end{array}$ & 5,747 & 1,990 & & & $\begin{array}{l}\text { thitung }>\text { ttabel yang } \\
\text { menyatakan bahwa } \\
H_{\text {a diterima yang }} \\
\text { berarti } H_{2} \text { diterima }\end{array}$ \\
\hline 3 & $\begin{array}{l}\text { Terdapat Pengaruh } \\
\text { Fasilitas Belajar terhadap } \\
\text { Hasil belajar }\end{array}$ & 7,557 & 1,990 & & & $\begin{array}{l}\text { thitung }>\text { tabel yang } \\
\text { menyatakan bahwa } \\
H_{a} \text { diterima yang } \\
\text { berarti } H_{3} \text { diterima }\end{array}$ \\
\hline 4 & $\begin{array}{l}\text { 'erdapat pengaruh Secara } \\
\text { simultan Motivasi Kerja, } \\
\text { Disiplin kerja dan } \\
\text { Fasilitas belajar terhadap } \\
\text { Hasil } \\
\text { belajar siswa. }\end{array}$ & & & 27,314 & 2,49 & $\begin{array}{l}\text { fhitung }>\text { ftabel yang } \\
\text { menyatakan bahwa } \\
H_{a} \text { diterima yang } \\
\text { berarti } H_{5} \text { diterima }\end{array}$ \\
\hline
\end{tabular}

\section{PEMBAHASAN}

Wahjosumidjo (2004) mengemukan bahwa motivasi adalah suatu usaha sadar untuk mempengaruhi perilaku seseorang agar supaya mengarah tercapainya tujuan organisasinya. Peran motivasi guru, baik internal maupun eksternal, sangat penting bagi terciptanya guru yang profesional. karena motivasi inilah yang menentukan perilaku orang-orang untuk bekerja, atau dengan kata lain, perilaku merupakan cerminan yang paling sederhana dari motivasi.

Temuan penelitian ini juga sejalan dengan temuan penelitian Siparno (2009) di SMP Negeri di Kecamatan Pamelang Kabutaten pamelang Provinsi Jawa Tengah Bahwa Termasuk dalam katagori tinggi. Perbuatan atau tingkah laku tujuan, 
kepuasan dan meningkatnya kinerja. oleh karna itu motivasi kerja guru sebagai pendidik sangat dibutuhkan untuk meningkatkan Hasil belajar siswa dan motivasi yang tinggi akan meninkatan prestasi dan Hasil belajar siswa. Motivasi kerja merupakan salah satu faktor yang ikut menentukan tinggi rendahnya Hasil belajar siswas. Motivasi juga berhubungan dengan faktor-faktor psikologis seseorang sebagai wujud hubungan antara sikap, kebutuhan dan kepuasan yang terjadi dalam diri manusia. Rangsangan bagi manusia adalah berusaha memenuhi kebutuhannya baik yang bersifat material maupun non material. Pemenuhan kebutuhan yang bersifat material merupakan motivasi kerja yang berasal dari luar individu guru namun besar pengaruhnya kepada kondisi kepuasan psikologis seorang guru. Terpenuhinya kebutuhan guru, minimal kebutuhan pokoknya, guru akan lebih fokus dalam bekerja dan menunjukkan kinerja sehingga dapat meningkatkan hasil belajar siswa.

Disiplin kerja guru di SMK Negeri 4 kota Jambi yang mana dapat kita lihat atau penulis paparkan bahwa disiplin kerja guru pada indikator yang paling tinggi dengan skor Mean yaitu pada indikator kesadaran dalam bekerja dan skor yang terendah yaitu pada skor nian pada indikator ketepatan waktu namun secara keseluruhan dapat penulis paparkan bahwa ke semua indikator tersebut masuk dalam kategori tinggi atau baik dengan rata-rata skor, ringan 3,5 iya disiplin kerja guru pada sumpah indikator tersebut sudah sana Baik atau tinggi hatinya disiplin guru di SMK Negeri 4 kota Jambi sudah sangat bagus dan tinggi dan baik hal ini sejalan dengan temuan penelitian lainya yaitu Rohmalia (2014) bahwa disiplin kerja guru di SMP, MTs dan MA Takhassus Al Quran Demak termasuk dalam kategori baik.

Simamora (2006) menyatakan bahwa Disiplin adalah prosedur yang mengoreksi atau menghukum bawahan karena melanggar peraturan atau prosedur. Disiplin merupakan bentuk pengendalian diri karyawan dan pelaksanaan yang teratur dan menunjukkan tingkat kesungguhan tim kerja di dalam suatu organisasi". Kinerja guru juga ditentukan oleh disiplin kerja yang tinggi. Dengan demikian sekolah yang di dalam proses belajar- mengajar tumbuh kedisiplinan, akan berfungsisebagai pembentuk nilai dan norma individu, penguasaan diri, sikap dan tanggung jawab bagi guru.. Kedisiplinan adalah kesadaran dan kesediaan seseorang dalam mentaati semua peraturan organisasi dan norma sosial yang berlaku (Hasibuan, 2017).

Dampak atau implikasi dari temuan penelitian ini adalah disiplin guru di SMK DB 4 dapat dipertahakan sehingga dalam kegiatan pendidikan dapat terlaksana dengan baik, hal ini dapat terlihat dari ketepatan waktu kerja, etika berpakaian, serta penggunaan fasilitas atau sarana kantor secara efektif dan efisien sehinga belajar mengajar menjadi lebih baik.

Pemetaan fasilitas belajar siswa di SMK Negeri 4 kota Jambi yang mana dapat kita paparkan atau penulis Jelaskan bahwa setiap indikator masuk dalam 
kategori tinggi namun ada beberapa indikator yang memiliki skor mean tinggi dibandingkan dengan indikator yang lain yang mana pada perpustakaan dan laboratorium sudah sangat memadai itu sangat baik kondisinya di SMK 4 kota Jambi di mana skor men pada indikator ini tertinggi dibandingkan dengan indikator yang lain sedangkan indikator terendah yaitu pada media pembelajaran dengan skor mean sebesar 3,5 sebenarnya skor ini menunjukkan bahwa fasilitas belajar siswa baik pada media pembelajaran alat pembelajaran gedung sekolah yang memadai rumah ruangan dan tempat belajarnya yang memadai, perpustakaan dan semua fasilitas ini sudah tersedia dengan baik di SMK Negeri 4 kota Jambi Berdasarkan pernyataan yang telah dipaparkan oleh responden yaitu siswa di SMK Negeri 4 Kota Jambi.

Untuk menggambarkan dan mengukur variabel hasil prestasi belajar siswa dalam hal ini peneliti mengambil instrumen dari nilai Rata - Rata Nilai Rapor Siswa kelas X pada Semester Genap tahun ajaran 2019/2020 yang dapat dilihat dalam Tabel 4.18 .

Tabel 4.18. menjelaskan frekuensi dari hasil belajar siswa yang dilihat dari keseluruhan hasil Rata - Rata Nilai Raport Siswa Kelas X dapat diinformasikan bahwa hasil prestasi siswa dari hasil Rata Rata Nilai Raport Siswa sebanyak 13 atau 15,5 \% mendapat Rata - rata Nilai rendah dan sebanyak 22 peserta atau siswa mendapat nilai tinggi dengan persentase $26,2 \%$ dan 58 orang siswa mendapat nilai sangat tinggi sebanyak 58 orang dengan persentase $58,3 \%$ artinya dapat disimpulkan bahwa hasil belajar Siswa Kelas X di SMK DB 4 Kota Jambi. Dimana tabel frekuensi ini hanya mewakili populasi Siswa Kelas X saja.

Pengujian hipotesis 1 , dilakukan dengan membandingkan thitung dengan ttabel. Dari tabel dapat dilihat nilai thitung variabel $\left(X_{1}\right)$ adalah sebesar 7,998. Sedangkan $t_{\text {tabel }}$ dapat dilihat dari tabel statistik taraf signifikan 0,05 (uji dua sisi) dengan derajat kebebasan (df) n-k atau 82-4=78, nilai ttabel yang diperoleh sebesar 1,990 sehingga thitung $>$ tabel $(7,998>1,996)$ maka $H_{0}$ ditolak. Nilai signifikan variabel $\left(X_{1}\right)$ adalah sebesar $0,000(<0,05)$ dengan nilai $\beta$ sebesar 0,000 . Dengan demikian $\mathrm{H}_{\mathrm{o}}$ ditolak dan menerima $\mathrm{H}_{\alpha}$. Hal ini menunjukkan bahwa Motivasi kerja berpengaruh positif dan signifikan terhadap Hasil belajar Siswa..

Penelitian ini sejalan dengan penelitian yang dilakukan oleh Wahjosumidjo (2004) Mengemukan Bahwa motivasi adalah suatu usaha sadar untuk mempengaruhi perilaku seseorang agar supaya mengarah tercapainya tujuan organisasinya. Peran motivasi guru, baik internal maupun eksternal, sangat penting bagi terciptanya guru yang profesional. karena motivasi inilah yang menentukan perilaku orang-orang untuk bekerja, atau dengan kata lain, perilaku merupakan cerminan yang paling sederhana dari motivasi

Temuan penelitian ini juga sejalan dengan temuan penelitian Siparno (2009) di SMP Negeri di Kecamatan Pamelang Kabutaten pamelang Provinsi Jawa Tengah Bahwa Termasuk dalam katagori tinggi Nastiti Amalda dan Lantip Diat Prasojo (2018) yang berjudul “Pengaruh Motivasi Kerja Guru, Disiplin Kerja Guru, dan 
Kedisiplinan Siswa Terhadap Prestasi Belajar Siswa". Hasi penelitian ini dapat ditarik kesimpulan bahwa pengaruh antara motivasi kerja guru terhadap prestasi belajar siswa SMA/MA di kota Mataram sejumlah 13,1\%.

Stevani (2016) yang berjudul "Analisis Disiplin Kerja Guru dan Motivasi Belajar Terhadap Prestasi Belajar Siswa Pada Mata Pelajaran IPS Kelas VIII di SMP N 8 Padang". Hasil penelitian ini dapat ditarik kesimpulan bahwa adanya pengaruh positif dan signifikan antara disiplin kerja guru terhadap hasil belajar siswa kelas VIII di SMP N 8 Padang. Adanya pengaruh positif dan signifikan antara motivasi belajar terhadap hasil belajar siswa kelas VIII di SMP N 8 Padang. Adanya pengaruh positif dan signifikan antara disiplin kerja guru dan motivasi belajar terhadap hasil belajar siswa kelas VIII di SMP N 8 Padang. Berdasarkan hasil tersebut, meningkatkan prestasi belajar siswa dapat diupayakan dengan meningkatkan kedisiplinan kerja guru, sehingga motivasi belajar meningkatkan dan hasil belajar akan mengalami peningkatan.

Pengujian hipotesis 2, dilakukan dengan membandingkan thitung dengan ttabel. Dari tabel dapat dilihat nilai thitung variabel $\left(X_{2}\right)$ adalah sebesar 5,747. Sedangkan $t_{\text {tabel }}$ dapat dilihat dari tabel statistik taraf signifikan 0,05 (uji dua sisi) dengan derajat kebebasan (df) n-k atau 82-4= 78, nilai tabel yang diperoleh sebesar 1,990 sehingga thitung $>$ tabel $(5,747>1,996)$ maka $H_{0}$ ditolak. Nilai signifikan variabel $\left(X_{2}\right)$ adalah sebesar $0,000(<0,05)$ dengan nilai $\beta$ sebesar 0,000 . Dengan demikian $H_{\circ}$ ditolak dan menerima $\mathrm{H}_{\alpha}$. Hal ini menunjukkan bahwa Disiplin kerja berpengaruh positif dan signifikan terhadap Hasil belajar Siswa..

R menunjukkan regresi Disiplin Kerja Guru sekolah Terhadap Hasil belajar/ Prestasi belajar siswa yaitu 0,287 masuk dalam kategori Lemah. Adapun R Square pada tabel di atas menunjukkan nilai koefesien determinasi disiplin Kerja guru Terhadap Prestasi/ Hasil Belajar siswa sebesar 0,287 atau sebesar 28,7\%. Dengan demikian, berarti bahwa Hasil belajar siswa diprediksi sebesar 28,7\% dapat dijelaskan oleh Disiplin Kerja guru sisanya sebesar 71,3\% dijelaskan oleh variablevariabel yang belum dimasukkan ke dalam model.

Penelitian ini sejalan dengan Nastiti Amalda dan Lantip Diat Prasojo (2018) yang berjudul "Pengaruh Motivasi Kerja Guru, Disiplin Kerja Guru, dan Kedisiplinan Siswa Terhadap Prestasi Belajar Siswa”. Hasi penelitian ini dapat ditarik kesimpulan bahwa pengaruh antara motivasi kerja guru terhadap prestasi belajar siswa SMA/MA di kota Mataram sejumlah 13,1\%. Pengaruh antara disiplin kerja guru terhadap prestasi siswa SMA/MA di Kota Mataram sejumlah 9,9\%. Pengaruh antara kedisiplinan siswa dan prestasi belajar siswa SMA/MA di Kota Mataram sejumlah 7,8\%. Pengaruh motivasi kerja guru, disiplin kerja guru, dan kedisiplinan siswa secara bersama-sama mempengaruhi prestasi belajar siswa SMA/MA di Kota Mataram sejumlah 34\%.

Stevani (2016) yang berjudul "Analisis Disiplin Kerja Guru dan Motivasi Belajar Terhadap Prestasi Belajar Siswa Pada Mata Pelajaran IPS Kelas VIII di SMP N 
8 Padang". Hasil penelitian ini dapat ditarik kesimpulan bahwa adanya pengaruh positif dan signifikan antara disiplin kerja guru terhadap hasil belajar siswa kelas VIII di SMP N 8 Padang. Adanya pengaruh positif dan signifikan antara motivasi belajar terhadap hasil belajar siswa kelas VIII di SMP N 8 Padang. Adanya pengaruh positif dan signifikan antara disiplin kerja guru dan motivasi belajar terhadap hasil belajar siswa kelas VIII di SMP N 8 Padang. Berdasarkan hasil tersebut, meningkatkan prestasi belajar siswa dapat diupayakan dengan meningkatkan kedisiplinan kerja guru, sehingga motivasi belajar meningkatkan dan hasil belajar akan mengalami peningkatan.

Dari uraian di atas maka terdapat keterkaitan antara disiplin kerja dengan Hasil belajar/prestasi belajar siswa Artinya makin tinggi motivasi kerja seorang guru maka makin baik guru dalam mengajar sehingga meninkatkan prestasi belajar siswa.

\section{Pengaruh Fasilitas belajar terhadap Hasil belajar siswa}

Pengujian hipotesis 3, dilakukan dengan membandingkan thitung dengan tabel. Dari tabel dapat dilihat nilai thitung variabel $\left(\mathrm{X}_{2}\right)$ adalah sebesar 7,557. Sedangkan tabel dapat dilihat dari tabel statistik taraf signifikan 0,05 (uji dua sisi) dengan derajat kebebasan (df) n-k atau 82-4=78, nilai tabel yang diperoleh sebesar 1,990 sehingga thitung $>$ tabel $(7,557>1,996)$ maka $H_{0}$ ditolak. Nilai signifikan variabel (X3) adalah sebesar 0,000 $(<0,05)$ dengan nilai $\beta$ sebesar 0,000 . Dengan demikian $\mathrm{H}_{\mathrm{o}}$ ditolak dan menerima $\mathrm{H}_{\alpha}$. Hal ini menunjukkan bahwa Fasilitas belajar berpengaruh positif dan signifikan terhadap Hasil belajar Siswa..

R menunjukkan regresi Fasilitas belajar siswa Terhadap Hasil belajar/ Prestasi belajar siswa yaitu 0,411 masuk dalam kategori Moderat. Adapun R Square pada tabel di atas menunjukkan nilai koefesien determinasi disiplin Kerja guru Terhadap Prestasi/ Hasil Belajar siswa sebesar 0,411 atau sebesar 41,1\%. Dengan demikian, berarti bahwa Hasil belajar siswa diprediksi sebesar 41,1\% dapat dijelaskan oleh Fasilitas belajar siswa sisanya sebesar 58,9\% dijelaskan oleh variablevariabel yang belum dimasukkan ke dalam model.

Muzdalidatuz Zahrotul Jannah (2017) "Pengaruh Fasilitas Belajar dan Motivasi Belajar terhadap Prestasi Belajar Siswa kelas V Pada Mata Pelajaran Matematika di MI Bustanul Ulum Brudu Sumbito Jombang" Hasil penelitian ini dapat ditarik kesimpulan bahwa adanya pengaruh signifikan antara fasilitas belajar terhadap prestasi belajar. Adanya pengaruh signifikan antara motivasi belajar terhadap prestasi belajar. Adanya pengaruh signifikan antara fasilitas belajar dan motivasi belajar terhadap prestasi belajar.

Amah \& Nugroho(2016). Pengaruh Fasilitas Sekolah Terhadap Hasil Belajar Akuntansi Dengan Lingkungan Sosial Sebagai Pemoderasi. Journal of Accounting and Business Education, 2(4). Hasil penelitian menunjukan bahwa fasilitas sekolah maupun Lingkungan sosial secara parsial berpengaruh signifikan terhadap hasil belajar siswa kelas XI dan XII IPS 1 MAN 1 Madiun.Hasil uji nilai selisih mutlak 
menunjukan bahwa variabel lingkungan sosial merupakanvaiabel pemoderasi yang mampu memperkuat pengaruh fasilitas sekolah terhadap hasil belajar siswa. Secara simultan variabel fasilitas sekolah dan lingkungan sosial bepengaruh terhadap hasil belajar siswa

Kurniawan, (2013). Pengaruh lingkungan sekolah, motivasi belajar dan fasilitas belajar terhadap hasil belajar siswa pada mata pelajaran peralatan kantor kelas X administrasi perkantoran SMK Negeri 1 Kudus tahun pelajaran 2012/2013. Economic Education Analysis Journal, 2(3).Secara parsial (uji t) variabel lingkungan sekolah (X1) diperoleh thitung $=6,984$ dengan signifikasi $0,000<0,05$ sehingga $\mathrm{H} 0$ ditolak. Variabel motivasi belajar $(X 2)$ diperoleh thitung $=3,872$ dengan signifikasi 0,000<0,05 sehingga H0 ditolak. Variabel fasilitas belajar (X3) diperoleh thitung = 5,809 dengan signifikasi 0,000<0,05 sehingga H0 ditolak. Secara simultan (R2) lingkungan sekolah, motivasi belajar dan fasilitas belajar berpengaruh terhadap hasil belajar siswa sebesar $64,1 \%$.

Hipotesis 4 dapat dilihat dari nilai $F_{\text {hitung }}$ sebesar 27,214. Nilai ftabel dapat dilihat pada tabel statistik dengan taraf signifikansi 0.05 dengan derajat kebebasan (df1) k-1 atau 4-1=3, (df2) n-k atau 82-4=78, nilai ftabel yang diperoleh sebesar 2.49 sehingga $f_{\text {hitung }}>\mathrm{f}_{\text {tabel }}$ yaitu sebesar $\left(27,314>2.49\right.$ maka $\mathrm{H}_{0}$ ditolak dan menerima $\mathrm{H}_{\alpha}$, dengan tingkat signifikan sebesar $0.000(<0.05)$. Maka pengujian diatas menunjukkan bahwa terdapat pengaruh antara Motivasi Guru, Disiplin Kerja, dan Fasilitas belajar secara simultan terhadap hasil belalajar siswa di SMK DB 4 Kota Jambi.

Koefesien Determinasi $\left(\mathrm{R}^{2}\right)$ merupakan cara untuk menilai seberapa besar konstruk endogen dapat dijelaskan oleh konstruk eksogen. Nilai koefisien determinasi $\left(\mathrm{R}^{2}\right)$ diharapkan antara 0 dan 1 . Jika nilai $\mathrm{R}^{2} 0,75,0,50$, dan 0,25 menunjukkan bahwa model kuat, moderat, dan lemah (Sarstedt dkk., 2017). Chin dalam Ghozali dan Latan (2015) memberikan kriteria nilai $\mathrm{R}^{2}$ sebesar 0,67; 0,33; dan 0,19 sebagian kuat, moderat, dan lemah. Adapun hasil pengukuran penelitian ini dengan menggunakan koefesien determinasi $\left(\mathrm{R}^{2}\right)$ dapat dilihat pada tabel 4.19 diatas.

Berdasarkan analisis tabel di atas menunjukkan angka Adjust $R$ Square adalah 0, 506 masuk dalam kategori moderat artinya 50,6\% variabel terikat Hasil belajar/prestasi belajar siswa yang dijelaskan oleh variabel bebas yang terdiri dari Motivasi kerja guru, Disiplin kerja guru, Fasilitas blajar siswa dan dan sisanya sebesar 49,70 \% dijelaskan oleh variabel lain diluar variabel yang digunakan. Jadi sebagian besar variabel terikat dijelaskan oleh variabel diluar variabel-variabel bebas yang tidak digunakan dalam model ini.

Andika (2012). Analisis data menggunakan analisis regresi berganda. Hasil penilitian menunjukkan bahwa analisis regresi linear berganda diperoleh persamaan: $\mathbf{Y}=\mathbf{4 0 , 7 1 7}+\mathbf{0 , 2 7 1 X} 1+0,210 X 2$. Uji F diperoleh Fhitung =13,205, sehingg a H3 diterima. ecara parsial (uji $\mathrm{t}$ ) variabel motivasi belajar (X1)diperoleh thitung = 3,354, sehungga diterima. Variabel Fasilitas belajar (X2)diperoleh thitung $=3,054$, sehingga $\mathrm{H} 2$ diterima. Secara simultan (R2) motivasi belajar dan fasilitas belajar 
berpengaruh terhadap prestasi belajar siswa sebesar 30,4\%

Yuniasih (2012) Hasil uji regresi linier berganda menunjukkan motivasi belajar berpengaruh terhadap prestasi belajar dengan taraf signifikansi 0,007<0,05. Fasilitas belajar berpengaruh terhadap prestasi belajar dengan taraf signifikansi $0,032<0,05$. Motivasi belajar dan fasilitas belajar berpengaruh terhadap prestasibelajar dengan taraf signifikansi $0,000<0,05$

\section{KESIMPULAN}

Bedasarkan analisis hasil penelitian dan pembahasan yang telah diuraikan sebelumnya maka dapat disimpulkan sebagai berikut :

Motivasi kerja Guru di SMK DB 4 Kota Jambi masuk dalam katagori baik/ tinggi. variabel motivasi yang mana dari ke tujuh sub indikator pada variabel motivasi pada indikator suasana kerja merupakan skor mean dengan kategori skor paling tinggi bandingkan dengan pada indikator lain dengan skor terendah yaitu pada indikator penghargaan namun secara keseluruhan pada motivasi kerja guru di SMK Negeri 4 kota Jambi seluruhnya masuk dalam kategori tinggi artinya baik

Disiplin kerja Guru di SMK DB 4 Kota Jambi masuk dalam katagori baik/ tinggi, disiplin kerja guru di SMK DB 4 kota Jambi yang mana dapat kita lihat atau penulis paparkan bahwa disiplin kerja guru pada indikator yang paling tinggi dengan skor Mean yaitu pada indikator kesadaran dalam bekerja dan skor yang terendah yaitu pada skor nian pada indikator ketepatan waktu namun secara keseluruhan dapat penulis paparkan bahwa ke semua indikator tersebut masuk dalam kategori tinggi atau baik dengan rata-rata skor, ringan 3,5 iya disiplin kerja guru pada sumpah indikator tersebut sudah sana Baik atau tinggi hatinya disiplin guru di SMK Negeri 4 kota Jambi sudah sangat bagus dan tinggi dan baik Fasilitas belajar siswa di SMK DB 4 Kota Jambi masuk dalam katagori baik/ pemetaan fasilitas belajar siswa di SMK DB 4 kota Jambi yang mana dapat kita paparkan atau penulis Jelaskan bahwa setiap indikator masuk dalam kategori tinggi namun ada beberapa indikator yang memiliki skor mean tinggi dibandingkan dengan indikator yang lain yang mana pada perpustakaan dan laboratorium sudah sangat memadai itu sangat baik kondisinya di SMK DB 4 kota Jambi di mana skor mean pada indikator ini tertinggi dibandingkan dengan indikator yang lain. Sedangkan indikator terendah yaitu pada media pembelajaran dengan skor mean sebesar 3,5 sebenarnya skor ini menunjukkan bahwa fasilitas belajar siswa baik pada media alat pembelajaran. Gedung sekolah yang memadai, ruangan dan tempat belajarnya yang memadai, perpustakaan dan semua fasilitas ini sudah tersedia dengan baik di SMK DB 4 kota Jambi.

Terdapat pengaruh motivasi kerja guru dengan prestasi belajar siswa, pengujian hipotesis 1, dilakukan dengan membandingkan thitung dengan tabel. Dari tabel dapat dilihat nilai thitung variabel $\left(X_{1}\right)$ adalah sebesar 7,998. Sedangkan $t_{\text {tabel }}$ dapat 
dilihat dari tabel statistik taraf signifikan 0,05 (uji dua sisi) dengan derajat kebebasan (df) n-k atau 82-4=78, nilai ttabel yang diperoleh sebesar 1,990 sehingga thitung $>t_{\text {tabel }}$ $(7,998>1,996)$ maka $\mathrm{H}_{0}$ ditolak

Terdapat pengaruh fasilitas belajar dengan prestasi belajar siswa, hipotesis 2, dilakukan dengan membandingkan thitung dengan tabel. Dari tabel dapat dilihat nilai thitung variabel $\left(\mathrm{X}_{2}\right)$ adalah sebesar 5,747. Sedangkan tabel dapat dilihat dari tabel statistik taraf signifikan 0,05 (uji dua sisi) dengan derajat kebebasan (df) n-k atau 82$4=78$, nilai tabel yang diperoleh sebesar 1,990 sehingga $t_{\text {hitung }}>t_{\text {tabel }}(5,747>1,996)$ maka $\mathrm{H}_{0}$ ditolak

Terdapat pengaruh disiplin kerja guru dengan prestasi belajar siswa, hipotesis 3, dilakukan dengan membandingkan thitung dengan tabel. Dari tabel dapat dilihat nilai thitung variabel $\left(X_{2}\right)$ adalah sebesar 7,557. Sedangkan tabel dapat dilihat dari tabel statistik taraf signifikan 0,05 (uji dua sisi) dengan derajat kebebasan (df) n-k atau $82-4=78$, nilai tabel yang diperoleh sebesar 1,990 sehingga thitung $>t_{\text {tabel }}$ $(7,557>1,996)$ maka $\mathrm{H}_{0}$ ditolak

Terdapat pengaruh motivasi kerja guru, disiplin kerja guru, dan fasilitas belajar terhadap prestasi belajar siswa, Hipotesis 4 dapat dilihat dari nilai $F_{\text {hitung }}$ sebesar 27,214. Nilai $\mathrm{f}_{\text {tabel }}$ dapat dilihat pada tabel statistik dengan taraf signifikansi 0.05 dengan derajat kebebasan (df1) k-1 atau 4-1=3, (df2) n-k atau 82-4=78, nilai ftabel

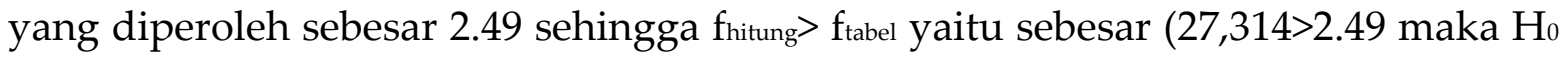
ditolak dan menerima $\mathrm{H}_{\alpha}$.

\section{DAFTAR PUSTAKA}

Amah, N., \& Nugroho, A. D. (2016). Pengaruh Fasilitas Sekolah Terhadap Hasil Belajar Akuntansi Dengan Lingkungan Sosial Sebagai Pemoderasi. Journal of Accounting and Business Education, 2(4).

Amalda, N., \& Prasojo, L. D. (2018). Pengaruh motivasi kerja guru, disiplin kerja guru, dan kedisiplinan siswa terhadap prestasi belajar siswa. Jurnal Akuntabilitas Manajemen Pendidikan, 6(1), 11-21.

Andika, M., \& Madjid, I. (2012). Analisis Pengaruh Sikap, Norma Subyektif dan Efikasi Diri Terhadap Intensi Berwirausaha Pada mahasiswa Fakultas Ekonomi Universitas Syiah Kuala. In Eco-Entrepreneurship Seminar \& Call for Paper" Improving Performance by Improving Environment (pp. 190-196).

Ghozali, I., \& Latan, H. (2015). Partial Least Squares, konsep, teknik dan aplikasi menggunakan program Smartpls 3.0 untuk penelitian empiris. Semarang: Badan Penerbit UNDIP.

Ghozali, Imam. 2009. Aplikasi Analisis Multivariate dengan Program SPSS. Badan Penerbitan Universitas Diponogoro.

Hasibuan, Malayu. 2017. Manajemen Sumber Daya Manusia. Jakarta: Bumi Aksara

Kurniawan, (2013). Pengaruh lingkungan sekolah, motivasi belajar dan fasilitas 
belajar terhadap hasil belajar siswa pada mata pelajaran peralatan kantor kelas $X$ administrasi perkantoran SMK Negeri 1

Muspawi, Mohamad. (2020). The Role of Leaders In Increasing Motivation Teacher Work In Pondok Pesantren. Ta'dib: Jurnal Pendidikan Islam. Vol.9.No.1.2020.p.1. EISSN: 25285092. PISSN: 14118173. DOI: https://doi.org/10.29313/tjpi.v9i1.5932 https://elearning2.unisba.ac.id/index.php/tadib/article/view/5932

Rohmalia, L., \& Djastuti, I. (2014). Analisis Pengaruh Motivasi dan Disiplin Kerja Terhadap Kepuasan Kerja Untuk Meningkatkan Kinerja Guru SMP, MTs dan MA Takhassus Al-Qur'an Demak (Doctoral dissertation, Fakultas Ekonomika dan Bisnis).

Sholeh, Asroun Niam. 2006. Membangun Profesionalisme Guru. Jakarta: Elsas. Siswoyo, Dwi. 2011. Ilmu Pendidikan. Yogyakarta: UNY Press.

Sudjana, Nana. 2011. Dasar-Dasar Proses Belajar Mengajar. Bandung: Sinar Baru Algensindo

Stevani, S. (2015). Analisis Disiplin Kerja Guru dan Motivasi Belajar terhadap Prestasi Belajar Siswa pada Mata Pelajaran IPS Kelas VIII di SMP N 8 Padang. Economica: Jurnal Program Studi Pendidikan Ekonomi STKIP PGRI Sumatera Barat, 4(1), 102108.

Wahjosumidjo. 2001. Kepemimpinan Kepala Sekolah. Jakarta: Raja Grafindo. 